\title{
Trees in Canadian Cities: Indispensable Life Form for Urban Sustainability
}

\section{Peter N. Duinker ${ }^{1}$,*, Camilo Ordóñez ${ }^{1}$, James W. N. Steenberg ${ }^{2}$, Kyle H. Miller ${ }^{3}$, Sydney A. Toni ${ }^{1}$ and Sophie A. Nitoslawski ${ }^{1}$}

1 School for Resource and Environmental Studies, Dalhousie University, 6100 University Ave., Halifax, NS B3H 4R2, Canada; E-Mails: camilo.ordonez@ dal.ca (C.O.); sydney.toni@dal.ca (S.A.T.); sophie.nitoslawski@dal.ca (S.A.N.)

2 Environmental Applied Science and Management, Ryerson University, Toronto, ON M5B 2K3, Canada; E-Mail: james.steenberg@ ryerson.ca

3 Geography and Program in Planning, University of Toronto, Toronto, ON M5S 3G3, Canada; E-Mail: kyle.miller@mail.utoronto.ca

* Author to whom correspondence should be addressed; E-Mail: peter.duinker@ dal.ca; Tel.: +1-902-494-7100; Fax: +1-902-494-3728.

Academic Editors: Tan Yigitcanlar and Md. Kamruzzaman

Received: 25 March 2015 / Accepted: 3 June 2015 / Published: 9 June 2015

\begin{abstract}
We argue that a healthy urban forest contributes immensely to the sustainability of cities. The argument is based on a comprehensive array of values elicited from Canadians in several cities. To begin, we define the urban forest as inclusive of all the trees in the city and thus representing the predominant contributor to a city's green infrastructure. Then we enumerate and explain the broad diversity of ways in which urban people value trees in the city. We, thus, show the myriad pathways by which trees contribute positively to any city's social, economic, and ecological sustainability. Following a short summary of the ways in which trees may detract from people's quality of life, we present promising management directions for urban-forest improvement, as we understand the situation in Canada. We conclude that all cities can enhance their sustainability by improving the urban forest.
\end{abstract}

Keywords: sustainability; tree; urban forest; forest values 


\section{Introduction}

The world is decidedly urban today, given that more than half of all humans live in cities [1]. The proportion is much higher in countries like Canada, where it is well over $80 \%$ [2]. The global trend toward urban living will continue for some decades. Clearly, the sustainability of human civilization depends to a great degree on determining sustainable pathways for city living and urban development.

Propositions for how to make urban living more sustainable are numerous and diverse and address a wide range of themes (Table 1). Such themes are, of course, not independent of each other; indeed, they are often deeply intertwined. In this paper, we argue that one particular type of plant, implicit in the "greenspace and biodiversity" theme in Table 1, has the potential to make immense contributions to city sustainability, not only in their own right but also as strong influences on most of the other themes. Those plants are trees, and together they define the urban forest.

Table 1. A selection of themes in the discourse of urban sustainability.

\begin{tabular}{cc}
\hline Theme & Reference(s) \\
\hline Community/Social Cohesion & {$[3,4]$} \\
Education & {$[5]$} \\
Employment & {$[6]$} \\
Energy & {$[7,8]$} \\
Food Security & {$[9,10]$} \\
Greenspace and Biodiversity & {$[11,12]$} \\
Human Health & {$[13,14]$} \\
Justice and Human Rights & {$[15-18]$} \\
Transportation & {$[19-21]$} \\
Urban Form and Design & {$[22,23]$} \\
Water and Air Quality & {$[24-26]$} \\
\hline
\end{tabular}

Our objective is to demonstrate, through the lens of values, the potency and promise of trees and their associated organisms to enhance sustainability in any urban setting. As Table 1 shows, urban sustainability consists of a broad range of elements. Without doubt, all these elements need to be carefully and diligently addressed in the pursuit of city sustainability. In the context of Canadian cities, our position on the centrality of trees is this: because people value trees so strongly and for such a wide range of benefits and services, and because both urban residents [27] and professionals [28] agree that more trees are highly desirable in the city, trees therefore represent a superlative opportunity for advancing urban sustainability.

By focusing on trees in this article, we do not imply that other plants are irrelevant. Indeed, shrubs and non-woody annual and perennial plants, even manicured grass, can be considered vital components of a city's green infrastructure. Some of the values we describe later in the paper can well be satisfied by these other types of plants, especially when they exist in association with trees. Trees are special and unique in the plant community for many reasons (see below), perhaps most profoundly because they predominate in contributing to the vertical dimension of the plant community on account of their height.

We begin with a contextual and conceptual discussion on sustainability and urban forests so as to lay a foundation under our claims of trees' contributions to sustainability. The main part of the paper 
highlights the diverse suite of values people ascribe to trees in the city (these are sometimes also called urban-forest benefits or services). To be fair to a comprehensive treatment of how trees and people in the city interact, we identify several ways in which trees can be detrimental to urban dwellers. Finally, we explain the main avenues for improving urban forests, particularly in the Canadian setting in which we, as urban-forest scholars, have most of our personal and professional experiences. The paper draws heavily on our research on these topics across Canada, as well as our ongoing work in support of planning and implementation of new directions for the urban forest in Halifax, Canada [29].

\section{Concepts of Sustainability in Relation to Cities}

As the places where most people on the planet live and work, cities have become central to both global socioeconomic development and environmental sustainability [30]. The concepts of development and sustainability are intertwined; entities such as the Organisation for Economic Co-operation and Development and the World Bank are now promoting urban sustainability for its value in attracting investment [31]. With virtually all worldwide population growth until 2050 expected to take place in urban areas, strategies for managing resource use and environmental degradation have become essential [32].

A city is, by itself, unsustainable. While calling them "parasites on the biosphere" may be extreme [33] (p. 290, as cited in [32]), it is true that cities depend on vast hinterlands for both essential resources and waste disposal [34]. Thus, rather than in absolute terms, urban sustainability is commonly conceptualized as a city's ability to maximize relative socioeconomic and environmental benefits while minimizing harm [35]. Within these broad categories, considerations of urban sustainability include inter- and intra-generational equity, protection of the natural environment, minimization of natural resource use, and community and individual well-being [36]. Considerable ambiguity remains in the definition of urban sustainability, but ambiguity is arguably desirable, because it allows communities to adopt individual understandings of sustainability that incorporate local values, circumstances, and environmental considerations [32].

Because cities concentrate people and wealth, they play a crucial role in global efforts to address climate change, but they also concentrate societal and infrastructural vulnerability to natural disasters [37]. However, while city living in developed countries generally remains more environmentally friendly than the alternatives [38], the reverse may hold in developing countries, although that is slowly changing [1]. Many cities, particularly in middle-income countries, have begun to lead by example, promoting compact urban forms, encouraging non-motorized modes of transportation, and (re)introducing efficiency concepts, such as passive solar design [39]. For true urban sustainability, cities must implement a wide range of interventions, from high-level policy to new technological solutions, to adjustments in building materials and streetscape [32].

The last two decades have also witnessed increasing focus on urban sustainability reporting, from Maclaren [36] identifying a dearth of clear reporting methods to the recent compilation of many new urban sustainability indicator methods [35]. Many urban sustainability indicator frameworks now explicitly address the urban forest canopy, including ISO standard \#37120, "Sustainable Development of Communities" [40]. It is clear that urban sustainability is a complex phenomenon requiring concerted attention to a host of economic, social, and environmental issues. 


\section{Conceptions of Urban Forests}

In dialogues and policy forums across the globe, from sub-national to global levels, there is a wide range of definitions and conceptions of forest and tree. A forest is usually conceived as a tree-dominated ecosystem. A key question, though, is what "dominated" means. When are the trees of insufficient size or density such that the ecosystem in question, rural or urban, is not considered a forest? In the urban setting, there are abundant sites and locations where the land cover is dominated by built infrastructure. Sometimes there are vast expanses of mowed grass with a few scattered trees. A conception of urban forest needs to account for such situations.

Defining a tree is somewhat less arbitrary, but there are still difficulties. One is the distinction between a shrub and a tree, both of which are woody plants but, at maturity, small ones are defined as shrubs whereas large ones are trees. For some species, the size threshold is arbitrary. For this paper, a tree is a living stem of a species determined by local, regional, or national authorities to be a tree species. Even minuscule seedlings of tree species are still trees.

Given the above, what is an urban forest? We find the most helpful conception to be an inclusion of all trees in the town or city [41]. In our own setting of the city of Halifax, the municipal government has jurisdiction over an area greater than a half-million hectares. The municipality has some $400 \mathrm{~km}$ of Atlantic coastline, and is largely wooded beyond the urban core. The Urban Forest Master Plan [29] applies only to what is called the urban core, which was defined as the territory in which all homes are serviced with municipal sewers and water.

Thus, once the urban boundary has been defined, the urban forest is defined as all trees within that boundary. The circumstances under which any urban tree might find itself are varied indeed. The definition is blind to land ownership. Whether trees are on private land (i.e., homes and businesses) or government land (i.e., municipal, provincial, national), they are all part of the urban forest. Whether a tree is standing alone in a grassy park or a tree pit on a busy commercial street, in a row of trees along a residential street, grouped in a back yard, or in a dense stand in an urban wooded park, it is part of the urban forest. The discussion below on values associated with urban trees makes it clear that each and every tree in the city has the potential to make a significant contribution to sustainability of the urban environment. Each and every tree is a contributor to the city's green infrastructure.

\section{How Trees Contribute to Sustainability of Cities}

The premise of this paper is that trees make strong contributions to desirable ecological, social, and economic conditions in any city, which can be interpreted as enhancing the city's sustainability. While the literature is replete with accounts of forest benefits, services, and values, the treatments of these in individual accounts is either broad and shallow — as in bare lists - or narrow and deep, as when one forest value, e.g., carbon sequestration, is examined at length. Our presentation below aims at a compromise between the two - our list is long, and we have presented a short explanation for each item presented.

We prefer the term "value" in our research because it helps citizens give considered responses to questions about what they deem to be important about trees in the city (see [42] for further justification). Our research group has recently engaged in studies of urban-forest values in selected Canadian cities (e.g., $[43,44]$ ), and has produced materials promoting trees in cities through enumeration of diverse 
forest values [45]. We draw upon this work in the following summary account of more than twenty ways in which trees contribute to urban sustainability. The list could be much longer-we regard the following ones as the leading forest values.

We acknowledge potential shortcomings of such a list. For example, some values (e.g., shade) are pre-requisites for or important influences on other values (e.g., extension of road-surface life, and enhancement of human heath). A reader may judge some of the values as substantially more important than others. The list is not logically established based on deductive reasoning-it arises from empirical research based mainly on what urban citizens say in answer to the importance question. Perhaps the values could be clustered into meaningful classes such as economic, social, and ecological values (e.g., [46]). All that said, we stand by the list as a broad suite of values identified, using the very words found below, in our survey, interview, and focus-group elicitations involving hundreds of people across Canada [27,43,44].

\section{A Suite of Urban-Forest Values}

Trees enhance the aesthetic beauty of the city. The idea that trees are pretty may be self-evident to any urban dweller as visions of green usually inspire calm and pleasant feelings. Indeed, city trees provide a wide set of visual pleasures, from the different colours of the leaves to the size and texture of tree trunks [47]. Trees also have sounds, such as when leaves rustle in the wind or a carpeted floor of fallen leaves is walked upon. Trees give people joy through the senses.

Trees provide shade. Shade is at the root of so many of the social, economic, and environmental benefits provided by trees in the city. It is a vital service in promoting people's health, as shade trees block harmful ultraviolet radiation [48]. Shade trees, especially ones that are strategically situated where people congregate outdoors like in parks and on sidewalks, can help to mitigate the risk of skin cancer. Children are especially vulnerable to skin cancer, and thus trees in playgrounds and school yards have the potential of significantly reducing their exposure and risk of skin cancer. Through shade, trees sustain human health.

Trees help conserve fuel by reducing emissions from parked vehicles. Outdoor parking lots can be considered miniature urban heat islands with extensive impervious surfaces and low albedo. Vehicles parked in sunlight heat up and emit hydrocarbons into the air from the fuel in their tanks. Well-placed trees can reduce the amount of fuel that evaporates into the atmosphere from vehicles [49]. Thus, trees conserve fuel while concurrently helping to sustain the urban atmosphere.

Trees cool the city environment. Due to their built infrastructure, cities frequently experience higher temperatures than the surrounding countryside - this is the urban heat-island effect [50]. Trees reduce ambient air temperatures by altering wind speeds, shading surfaces, and blocking solar radiation [51,52]. Trees also transpire water vapour into the air and, thus, cool it [53,54]. Consequently, the more trees there are in the city, the greater the cooling effect will be. This is especially relevant given expected climatic change and the associated warmer temperatures.

Trees clean the air. Air pollution is an issue for most cities, and urban trees help improve air quality. Gaseous pollutants like ground-level ozone, sulphur dioxide, nitrogen dioxide, and carbon monoxide are removed from the atmosphere by trees by absorbing them through their leaves [55]. Particulate matter 
is also removed from the air and stored temporarily on the plant surfaces until it washes off in the rain [56]. Overall air quality is better with more trees in the city.

Trees foster health and healing. Trees help purify the air and reduce rates of asthma and other respiratory illnesses in urban populations [57,58]. When we fall ill, or are convalescing from illness, trees can play a pivotal role in healing. Landmark research by Ulrich [59] showed that surgery patients recovered faster and better when the view through their hospital bedroom window was dominated by trees rather than another building. Research in Japan has shown clear health benefits from exposure to forest landscapes [60].

Trees enhance community safety. Security and safety are serious concerns in a city. Among the psychological causes of insecurity and feelings of danger, we find mental fatigue and elevated levels of stress. Although earlier research suggested that dense and naturally vegetated areas were perceived as insecure and threatening (e.g., [61]), these perceptions have been changing through the years with our understanding of how mental fatigue and stress are mitigated by green space and its most dominant feature-trees. More recent research shows that residents living in greener surroundings report lower levels of fear, fewer incivilities, and less aggressive and violent behaviour [62].

Trees increase property values. Trees in the city are a major component of a neighbourhood's aesthetic appeal and benefit homeowners by adding monetary value to properties. For Portland, Oregon, Donovan and Butry [63] found that a large tree on a residential property can add some $\$ 9000$ to the sale price of a house. Land owners are also helping others by having trees on their residential properties, because adjacent homes and even entire neighbourhoods benefit from the increased property value. This is an important message to communicate to homeowners, since there is frequently more available space to plant trees on private residential properties than next to publicly owned streets.

Trees reduce energy costs. In some places, roughly 5\%-10\% of urban electricity demand is spent on cooling/heating buildings. Trees around buildings and houses can act as heat insulators and heat absorbers, shielding buildings from a high-temperature environment through shade, or keeping buildings from losing their heat in winter by increasing the humidity of the surrounding area and slowing down wind [64]. Simulations in Canadian cities have shown that an increase in a neighbourhood's tree cover by about three trees per house reduces the heating energy of that house by up to $10 \%$ and the cooling energy by up to $40 \%$ [65]. The annual savings in heating and cooling costs can reach the hundreds of dollars every year depending on house size.

Trees prolong the life of infrastructure. Trees help reduce the amount of maintenance and repair required for city streets, thus reducing costs against the city budget. The asphalt used to pave streets is made up of aggregate held together by asphalt cement. The asphalt cement is a petroleum product, which breaks down and evaporates in the sunlight, causing streets to crack and eventually crumble into potholes, which need to be repaired, or the whole street repaved, at great cost. McPherson and Muchnik [66] found that just a $20 \%$ shading of streets in Modesto, California, could save $60 \%$ of resurfacing costs over a 30 -year period. This service provided by trees is a huge incentive for engineers and indeed all municipal managers to increase tree canopy over asphalt surfaces.

Trees capture and store carbon. Atmospheric carbon dioxide is one of the main drivers of climate change [67]. Its concentration in the air is rising largely because of the burning of fossil fuels like coal, oil, and gas [67]. Anything we can do to slow down emissions of carbon dioxide and increase the rate of its removal from the air will be good for the future of cities [68]. Trees capture carbon dioxide from 
the air and store the carbon in their trunks, roots, and branches. As long as a tree is healthy and growing, it stores increasing amounts of carbon. The more trees we have in the city, and the larger and longer they grow, the more carbon dioxide will be taken out of the atmosphere [69].

Trees slow down stormwater flow and consequently improve water quality. Urban land is covered mainly by roads, sidewalks, rooftops, and parking lots. Most of these surfaces are impervious and prevent rainwater from being absorbed directly into the ground. Consequently, stormwater and wastewater systems, as well as natural water bodies, are strained during heavy rains as runoff flows into them off impervious surfaces. Excessive runoff can lead to flooding, sewage spillover, and aquatic pollution. This is especially the case in cities like Halifax, where the older parts of the city have combined storm and sanitary sewers. City trees intercept some amounts of rainfall and retain it in their foliage for a period of time [70]. Trees, thus, provide a critical economic service in stormwater management.

Trees provide employment opportunities. As they grow up into overhead wires, shed their leaves, grow new branches in undesirable directions, drop dead branches, or die, trees are cared for by municipal workers as well as private landscape contractors and other specialized tree caretakers. Salaries make up large proportions of the budget of tree-care organizations. The more trees there are in a city, the greater the amount of economic activity associated with their maintenance [71]. Trees represent smart societal investments because they demand expenditures on caring for vital urban green infrastructure.

Trees support business activity. The services provided by trees provide tangible financial benefits to business owners. Research has shown that consumers perceive business districts with trees as better places to shop [72]. Moreover, consumers say they are willing to pay higher prices, travel further and longer, and shop longer and more frequently in areas with green streetscapes [73]. This not only benefits business owners, but also provides incentive for them to become more actively involved in the stewardship of urban trees.

Trees enhance recreational opportunities. City residents frequently visit treed areas for recreation. Recreation in these areas can be passive or active, ranging from gentle activities such as cultural events, walking, picnics, or tree climbing, to active sports such as running or biking [74,75]. The many types of urban forest formats, ranging from treed streets to dense and naturalized forest remnants, serve diverse recreational uses [76].

Trees enhance tourism. Among the few studies linking urban forests and tourism, Majumdar et al. [77] concluded that for Savannah, Georgia, the better the urban forest, the more attractive the city is for tourists. This seems a reasonable conclusion considering that most city residents would like more trees and better urban-forest management in their own cities [27]. All other things being equal, it seems fair to say that tourists would prefer to visit a well-wooded city as opposed to one with few trees.

Trees provide diverse foods. Trees have been a source of food for people throughout the ages. Urban settings are highly suitable for growing the full range of fruit and nut trees [78]. Additionally, there may be opportunities to pick edible berries and mushrooms that grow on the forest floor of treed parks and other naturalized areas. Thus, trees can contribute, even if in a small way, to food security in the city.

Trees conserve biodiversity. Biodiversity, in the simplest terms, refers to the full diversity of life on earth and includes the diversity of gene pools, species, communities and ecosystems. Trees themselves represent important elements of biodiversity, but they also serve as host and habitat for a wide range of other organisms. The ability of trees to contribute to urban biodiversity increases as one moves from single isolated trees to lines of trees along streets and lanes, and further to stands of trees in parks and 
other areas [79]. Urban forests can contribute immensely to biodiversity conservation through inclusion of the full range of native tree species in their full spectrum of ages and community associations [80].

Trees promote learning opportunities. Trees provide habitat for many kinds of wild organisms, including fungi, insects, lichens, birds, mammals, and other vascular plants. An excellent focus to start learning about terrestrial nature in the city is the trees. Indeed, there is no better place to learn about nature than to be in it [81]. Getting away from the city and out into natural forests can be costly and may even be impossible for some people. The alternative is to study nature in the city. Trees in the city can provide excellent opportunities to learn about the kinds of species and natural ecosystems there are in the countryside and the wilderness. Research has also shown that urban trees can enhance the learning capacity of learners [82].

Trees impart a sense of place. Feeling a sense of belonging in the city is important to its citizens. The vegetation of a locale can contribute strongly to this sense of place. The presence of trees transforms barren areas into pleasant, welcoming spaces that infuse the city environment with a positive sense of self [83]. It has been shown that well-kept treed neighbourhoods serve to strengthen the ties among residents, generating a sense of place and stewardship among neighbours [84]. This in turn generates important civic values such as a greater sense of safety and adjustment, more use of neighbourhood common spaces, and fewer incivilities [85].

Trees contribute to a sense of well-being. The main argument is that the more that people can experience nature, the better they feel, emotionally, mentally, and physically $[11,86,87]$. The lack of nature in cities means that many people cannot benefit from it as directly as they might. In many cities around the world, trees dominate the natural ecosystems. If we are to bring nature to the people in an urban environment, that means more trees, not just in total but also more trees in naturalized conditions (see [88]). A healthy urban forest contributes to a healthy and happy people.

To sum up, we conclude that trees boast an extensive and diverse array of values to cities. We suggest that they are the greatest contributors to urban sustainability of all forms of plants. In absolute terms, the contributions of trees to urban sustainability are substantial. The more trees there are in the city, the better the city can serve as a good place to live.

\section{Can Trees Detract from Urban Sustainability?}

Unfortunately, trees can be detrimental to urban dwellers in several ways. We believe that the benefits of trees outweigh the costs, but these potential inconveniences or risks should be taken into consideration when planning a sustainable city. Some costs may be unavoidable; some stem from the location of the tree in relation to infrastructure, others from tree species selection. Yet other costs relate to how well or how badly the built infrastructure accommodates trees.

Trees can damage infrastructure. Roots may crack sidewalks, and branches or whole trees can fall and cause damage during extreme weather events such as windstorms $[89,90]$. Roots are also know to invade underground drainage pipes [91], although this normally happens in the context of leaky pipes. Trees may require frequent maintenance to ensure they do not damage infrastructure, such as pruning programs to keep tree branches out of overhead wires [92]. Moreover, natural or disturbance-related mortality and the presence of standing deadwood both present a similar hazard or significant costs for removal, as is the case currently with widespread ash (Fraxinus spp.) mortality caused by the emerald 
ash borer (Agrilus planipennis) [93]. Similarly, trees can create unwanted debris, such as sap and leaves [93]. Lastly, infrastructure and people may be put at risk by the increase in wildfire potential that comes with an increase in urban trees [29].

Humans can have allergic reactions to the pollen produced by trees and plants in the urban forest [94,95]. Treed areas can create feelings of unease due to real or perceived danger [96]. Urban residents occasionally identify heightened feelings of unease and fear of crime in some treed urban areas due to the potential of concealed individuals or activities [85,97,98]. Trees provide habitat for other species, but not all these species may be desirable. Urban wildlife can annoy or threaten pets and humans, or damage plants and structures (e.g., birds and fruit trees) [99]. For example, in Helsinki, Finland, the excrement on sidewalks from aphids in linden trees produced a vomit-like odour during warm spells [100].

Tree shade may be valued by some but be seen as an inconvenience by others. Trees located over flower or food gardens can provide undesirable shade that limits the growth of more-desired plants, such as vegetables [101]. They may also hinder the growth of garden plants in the understory when their needles and leaves decompose. Thus, the location of a tree in its ecological and social contexts influences whether the tree's services are of value.

Similarly, tree shade that lowers summer cooling costs could increase winter heating costs [102]. Trees might be positioned in a way that limits winter sunlight, turning shade into a disservice [103]. While we generally think of street trees as cooling agents, they also have the potential locally to increase air temperatures. For example, a canopy of immature trees can block airflow but still allow solar radiation to strike and heat the ground [51].

The touted improvements in quality of life that trees bring can result in increased financial costs to nearby residents. The increase in property values from trees may result in an increased property tax for the owner. Dwyer et al. [104] conservatively estimated that, in the United States, \$1.5 billion/year in property taxes might be attributed to the value trees add to property. As trees increase the value of the spaces and buildings around them, the increased values benefit owners wishing to sell but represent higher real-estate costs for would-be buyers.

Trees and parks are differentially distributed in cities. Ethnic/racial minorities and low-income residents have lower access to green space $[105,106]$. While city planning that incorporates tree planting and park development in lower-income areas aims to rectify this social injustice, it also increases the desirability of these areas and can contribute to their gentrification, pushing out the original residents [107].

More trees means more maintenance. The equipment used for tree maintenance is usually powered by fossil fuels, so engine emissions need to be factored against trees' carbon-storage capabilities [102]. These costs might start to outweigh the benefits of trees if urban vegetation is short-lived or stressed, and requires constant attention or removal and replacement [108]. Lastly, some trees may not always be the optimal choice for a sustainable city. The water demands of many tree species may make them unsuitable for cities in arid and semi-arid climates [109].

Despite the above drawbacks of trees in the city, we reiterate our own views about the net benefits of trees, as well as what we perceive to be the trend in Canada based on our research [27,28]: the benefits of trees in the city far outweigh the drawbacks, and hence both professionals and citizens favour increases in urban tree canopy. When urban forests are managed well, as outlined below, the net benefits can be significantly increased. 


\section{Enhancing Urban Forests for City Sustainability}

Shaping the urban forest so it delivers on citizens' value expectations requires active and careful intervention - there is no passage without fare. Investment is needed to improve the supply of urban-forest services while also mitigating potential disservices. The majority of trees in the city require substantial management actions to maintain function and ensure tree establishment and survival. Cities represent rather different conditions from those under which tree species have evolved. An abundance of stressors and disturbances afflict city trees (e.g., poor soils, pollution, invasive species, vandalism, poor management), resulting in urban forests suffering relatively high rates of tree decline and mortality [110]. Ensuring that city dwellers live well among trees, and the challenges associated with doing so, has therefore spawned a wide array of policies and practises for maintaining and enhancing urban forests.

Urban forestry in North America, as a practice and profession that separated from traditional forestry in the 1960s, represents an amalgamation of forestry with horticulture, arboriculture, and landscape architecture [111]. Arguably, broad establishment and acceptance of urban forestry was cemented by the Dutch elm disease (Ophiostoma novo-ulmi), which ravaged the extensively planted elm (Ulmus spp.) populations of North American cities and first exposed the public to the consequences of widespread urban canopy loss [112]. While urban forest management in many ways remains reactive and practice-oriented, being driven by immediate disturbance and threats like the Dutch elm disease, more advanced and progressive models of urban forest governance are emerging [113]. Urban forest management today continues to grow beyond operational necessities like tree planting, maintenance, and removal.

Across Canada, the urban forest is increasingly becoming an item on municipal planning agendas and many cities are creating policies and strategic plans that address their urban forest [28,114]. The design and implementation of tree protection regulations for public and private properties are becoming commonplace in larger cities [115]. Many of these regulations focus on the formal planning process, since development practices and land-use change are among the largest contributors to urban tree mortality and canopy loss [116]. Trees also continue to garner attention in the urban design process as vital pieces of green infrastructure, where the realities of growing trees that survive to maturity is no longer an afterthought in landscape architecture and engineering [117]. Experiments are underway to explore how to grow trees on buildings - examples include the famous Hundertwasserhaus in Vienna and the Bosco Verticale (Vertical Forest) in Milan. The use of underground structural soil cells in high-density streetscapes is a prime example of designing cities for trees rather than adapting trees to cities [118].

Another growing trend in urban forest enhancement is incentive-based programs that offer financial or non-financial motivation for residents, businesses, and organizations to take part in urban forest stewardship activities (e.g., free-tree programs) with the long-term goal of changing citizen behaviours and fostering stewardship $[119,120]$. Lastly, many cities are adopting comprehensive and strategic urban forest management plans [28]. These plans generally consist of guidelines for tree planting and species selection, tree maintenance (e.g., pruning-cycle establishment), pest management, conservation goals, and performance standards [121]. Management plans are an important step for communities to acknowledge urban forests as a public good and a key stage of policy development for ensuring explicit and consistent goals for long-term sustainable urban forest management [122]. 
The complexity and heterogeneity of the urban forest and the growing importance of cities have demanded a more enlightened and interdisciplinary approach to understanding and managing them. This requires not only maintenance operations and municipal policies, but also ongoing research from the social, natural, and applied sciences, as well as partnerships involving governments, industry, academia, and communities [123]. In fact, today it is argued that urban forest management and governance have become particularly innovative as they often involve partnerships with a variety of non-government stakeholders, such as environmental non-governmental organizations, citizen associations, landowners, and industry [113]. Indeed, these partnerships are arguably necessary given the complex and fragmented ownership regimes of cities and their urban forests. Ultimately, it is the partnership between humans and trees that contributes to the overall sustainability of the modern city.

\section{Conclusions}

Municipal managers across Canada seek to increase the proportion of the urban landscape dominated by trees. This objective rests firmly on the understanding that trees are, on balance, extremely good for people and the city environment. We have shown above that trees offer a relatively much stronger and broader array of benefits to people compared to their negative aspects, suggesting that they are strong net contributors to urban sustainability. Careful and sensitive management of a city's tree population, with an eye to reducing tree disservices and increasing tree services, as well as catering to people's tree-related values, can substantially enhance those contributions.

Urban sustainability is a journey of improving city conditions economically, socially, and environmentally. It aims to improve the human condition in respect of people's health and welfare. City development is most often dominated by construction and maintenance of grey infrastructure, mostly buildings and transportation networks. Without question, such infrastructure is needed for a city to function. However, at one end of the spectrum, grey infrastructure can be developed with no regard to the quantity and quality of green infrastructure, i.e., trees and other plants. At the other end, it can be designed and installed to cater well to, and even celebrate, the green infrastructure. Sustainable urban development will proceed well when cities are reconceived from concentrations of concrete, steel, and asphalt sprinkled about with a few amenity trees, to a natural or semi-natural landscape into which concrete, steel, and asphalt are judiciously introduced. Where the former predominates, urban redevelopment is warranted with emphasis on renewal and expansion of green infrastructure. If the latter exists anywhere in the world, it is to be emulated and repeated. Trees are indeed indispensable for city sustainability.

\section{Acknowledgments}

Our urban-forest research has been funded by the Social Sciences and Humanities Research Council of Canada as well as Halifax Regional Municipality. We are grateful for the comments of two anonymous reviewers on an earlier version of the paper.

\section{Author Contributions}

Peter Duinker conceived the idea for the paper, served as principal investigator of all research grants and contracts pertaining to the topic, wrote several sections, submitted the manuscript, and implemented 
revisions. Camilo Ordóñez, James Steenberg, Kyle Miller, and Sydney Toni each drafted specific sections of the manuscript, and Sophie Nitoslawski edited the entire paper and contributed to early revisions. Ordóñez, Steenberg, Toni, and Nitoslawski are students or former students of Duinker and contributed to the many discussions that lie behind the concepts of urban-forest sustainability as documented herein.

\section{Conflicts of Interest}

The authors declare no conflict of interest. The research sponsors had no role in: the design of the study; the collection, analyses, and interpretation of data; the writing of the manuscript, and the decision to publish the results.

\section{References}

1. UN-HABITAT. The State of the World's Cities 12/13-Prosperity for Cities; United Nations HABITAT Programme, United Nations Human Settlements Programme (UN-HABITAT): Nairobi, Kenya, 2012. Available online: http://www.unhabitat.org/pmss/ (accessed on 1 March 2015).

2. Statistics Canada. Population, urban and rural, by province and territory (Canada). Available online: http://www.statcan.gc.ca/tables-tableaux/sum-som/101/cst01/demo62a-eng.htm (accessed on 1 March 2015).

3. Dempsey, N.; Bramley, G.; Power, S.; Brown, C. The social dimensions of sustainable development: Defining urban social sustainability. Sustain. Dev. 2011, 19, 289-300.

4. Vojnovic, I.; Darden, J.T. Class/racial conflict, intolerance, and distortions in urban form: Lessons for sustainability from the Detroit region. Ecol. Econ. 2013, 96, 88-98.

5. Trencher, G.P.; Yarime, M.; Kharrazi, A. Co-creating sustainability: Cross-sector university collaborations for driving sustainable urban transformations. J. Clean Prod. 2013, 50, 40-55.

6. Bugliarello, G. Urban sustainability: Dilemmas, challenges and paradigms. Technol. Soc. 2006, 28, 19-26.

7. Hawkey, D.; Webb, J.; Winskel, M. Organisation and governance of urban energy systems: District heating and cooling in the UK. J. Clean Prod. 2013, 50, 22-31.

8. Uyarra, E.; Gee, S. Transforming urban waste into sustainable material and energy usage: The case of Greater Manchester (UK). J. Clean Prod. 2013, 50, 101-110.

9. Koc, M.; MacRae, R.; Mougeot, L.J.A.; Welsh, J. (Eds.) For Hunger-Proof Cities: Sustainable Urban Food Systems; International Development Research Centre (IDRC): Ottawa, ON, Canada, 1999.

10. Barthel, S.; Isendahl, C. Urban gardens, agriculture, and water management: Sources of resilience for long-term food security in cities. Ecol. Econ. 2013, 86, 224-234.

11. Chiesura, A. The role of urban parks for the sustainable city. Landsc. Urban. Plan. 2004, 68, 129-138.

12. Dearborn, D.C.; Kark, S. Motivations for conserving urban biodiversity. Conserv. Biol. 2010, 24, 432-440.

13. Jackson, L.E. The relationship of urban design to human health and condition. Landsc. Urban. Plan. 2003, 64, 191-200.

14. Grahn, P.; Stigsdotter, U.K. Landscape planning and stress. Urban. For. Urban. Green. 2003, 2, $1-18$. 
15. Stephens, C. Healthy cities or unhealthy islands? The health and social implications of urban inequality. Environ. Urban. 1996, 8, 9-30.

16. Di Chiro, G.D. Nature as Community: The Convergence of Environment and Social Justice. In The Struggle for Environmental Democracy: Environmental Justice Movements in the United States; Faber, D.R., Ed.; The Guilford Press: New York, NY, USA, 1998.

17. Marcuse, P.; Connolly, J.; Novy, J.; Olivo, I.; Potter, C. Steil, J. Searching for the Just City: Debates in Urban Theory and Practice; Routledge: New York, NY, USA, 2009.

18. Pearsall, H.; Pierce, J. Urban sustainability and environmental justice: Evaluating the linkages in public planning/policy discourse. Local Environ. 2010, 15, 569-580.

19. Kenworthy, J.R.; Laube, F.B. Automobile dependence in cities: An international comparison of urban transport and land use patterns with implications for sustainability. Environ. Impact Assess. 1996, 16, 279-308.

20. Himanen, V.; Lee-Gosselin, M.; Perrels, A. Sustainability and the interactions between external effects of transport. J. Transp. Geogr. 2005, 13, 23-28.

21. Richardson, B.C. Sustainable transport: Analysis frameworks. J. Transp. Geogr. 2005, 13, 29-39.

22. Badland, H.; Schofield, G. Transport, urban design, and physical activity: An evidence-based update. Transport. Res. D 2005, 10, 177-196.

23. Ahern, J. Urban landscape sustainability and resilience: The promise and challenges of integrating ecology with urban planning and design. Landsc. Ecol. 2013, 28, 1203-1212.

24. Hellström, D.; Jeppsson, U.; Kärrman, E. A framework for systems analysis of sustainable urban water management. Environ. Impact Assess. 2000, 20, 311-321.

25. Fenger, J. Urban air quality. Atmos. Environ. 1999, 33, 4877-4900.

26. Milman, A.; Short, A. Incorporating resilience into sustainability indicators: An example for the urban water sector. Global Environ. Chang. 2008, 18, 758-767.

27. Ordóñez, C.; Duinker, P.N.; Sinclair, J.A.; Beckley, T.M. Public values of urban forests in Canada using a sidewalk-interception survey in Fredericton, Halifax, and Winnipeg. Arboricult. Urban. For. 2015, in press.

28. Ordóñez, C.; Duinker, P.N. An analysis of urban forest management plans in Canada: Implications for urban forest management. Landsc. Urban. Plan. 2013, 116, 36-47.

29. HRM Urban Forest Planning Team. Halifax Regional Municipality (HRM) Urban Forest Master Plan; Halifax Regional Municipality (HRM): Halifax, NS, Canada, 2013. Available online: https://www.halifax.ca/Property/UFMP/index.php (accessed on 1 March 2015).

30. Matusitz, J. Glurbanization theory: An analysis of global cities. Int. Rev. Sociol. 2010, 20, 1-14.

31. Davidson, K.; Gleeson, B. The sustainability of an entrepreneurial city? Int. Plan. Stud. 2014, 19, 173-191.

32. Vojnovic, I. Urban sustainability: Research, politics, policy and practice. Cities 2014, 41, S30-S44.

33. Odum, E.P. Ecology: Bridge between Science and Society; Sinauer Associates Incorporated: Sunderland, MA, USA, 1997.

34. Rees, W.; Wackernagel, M. Urban ecological footprints: Why cities cannot be sustainable_-And why they are a key to sustainability. Environ. Impact Assess. 1996, 16, 223-248. 
35. Mori, K.; Yamashita, T. Methodological framework of sustainability assessment in City Sustainability Index (CSI): A concept of constraint and maximisation indicators. Habitat Int. 2015, 45, 10-14.

36. Maclaren, V.W. Urban sustainability reporting. J. Am. Plann. Assoc. 1996, 62, 184-202.

37. Hoornweg, D.; Freire, M.; Lee, M.J.; Bhada-Tata, P.; Yuen, B. (Eds.) Cities and Climate Change: Responding to An Urgent Agenda; The World Bank: Washington, DC, USA, 2011.

38. Van Oers, R.; Roders, A.P. Editorial: Historic cities as model of sustainability. J. Cult. Herit. Manag. Sustain. Dev. 2012, 2, 4-14.

39. Jabareen, Y. Planning the resilient city: Concepts and strategies for coping with climate change and environmental risk. Cities 2013, 31, 220-229.

40. ISO. Sustainable Development of Communities-Indicators for City Services and Quality of Life; ISO 37120:2014; International Standards Organization (ISO): Geneva, Switzerland, 2014. Available online: http://www.iso.org/iso/catalogue_detail?csnumber=62436 (accessed on 1 March 2015).

41. Konijnendijk, C.C.; Ricard, R.M.; Kenney, A.; Randrup, T.B. Defining urban forestry: A comparative perspective of North America and Europe. Urban. For. Urban. Green. 2006, 4, 93-103.

42. Ordóñez, C.; Duinker, P.N. Interpreting sustainability for urban forests. Sustainability 2010, 2, 1510-1522.

43. Peckham, S.; Duinker, P.N.; Ordóñez, C. Urban Forest Values in Canada: Views of citizens in Calgary and Halifax. Urban. For. Urban. Green. 2013, 12, 154-162.

44. Sinclair, J.A.; Diduck, J.; Duinker, P.N. Elicitation of urban forest values from residents of Winnipeg, Canada. Can. J. For. Res. 2014, 44, 922-930.

45. CUFRG. In Support of Trees in the City: A Message for Municipal Councillors, Developers, and NGOs; Canadian Urban Forest Research Group (CUFRG), School for Resource and Environmental Studies, Dalhousie University: Halifax, NS, Canada, 2013. Available online: http://www.canadianurbanforest.ca (accessed on 1 March 2015).

46. Moyer, J.N.; Owen, R.J.; Duinker, P.N. Forest Values: A framework for old-growth forest with implications for other forest conditions. Open For. Sci. J. 2008, 1, 27-36.

47. Smardon, R.C. Perception and aesthetics of the urban environment: Review of the role of vegetation. Landsc. Urban. Plan. 1988, 15, 85-106.

48. Heisler, G.M.; Grant, R.H. Ultraviolet radiation in urban ecosystems with consideration of effects on human health. Urban. Ecosyst. 2000, 4, 193-229.

49. Scott, K.I.; Simpson, J.R.; McPherson, E.G. Effects of tree cover on parking lot microclimate and vehicle emissions. J. Arboricult. 1999, 25, 129-142.

50. Solecki, W.D.; Rosenzweig, C.; Parshall, L.; Pope, G.; Clark, M.; Cox, J.; Wiencke, M. Mitigation of the heat island effect in urban New Jersey. Global Environ. Chang. 2005, 6, 39-49.

51. Heisler, G.M. Effects of individual trees on the solar radiation climate of small buildings. Urban. Ecol. 1986, 9, 337-359.

52. Rosenfeld, A.H.; Akbari, H.; Romm, J.J.; Pomerantz, M. Cool communities: Strategies for heat island mitigation and smog reduction. Energy Build. 1998, 28, 51-62.

53. Streiling, S.; Matzarakis, A. Influence of single and small clusters of trees on the bio-climate of a city: A case study. J. Arboricult. 2003, 29, 309-316.

54. Armson, D.; Stringer, P.; Ennos, A.R. The effect of tree shade and grass on surface and globe temperatures in an urban area. Urban. For. Urban. Green. 2012, 11, 245-255. 
55. Nowak, D.J.; Crane, D.E.; Stevens, J.C. Air pollution removal by urban trees and shrubs in the United States. Urban. For. Urban. Green. 2006, 4, 115-123.

56. Freer-Smith, P.H.; Holloway, S.; Goodman, A. The uptake of particulates by an urban woodland: Site description and particulate composition. Environ. Pollut. 1997, 95, 27-35.

57. Tiwary, A.; Sinnett, D.; Peachey, C.; Chalabi, Z.; Vardoulakis, S.; Fletcher, T.; Leonardi, G.; Grundy, C.; Azapagic, A.; Hutchings, T.R. An integrated tool to assess the role of new planting in PM10 capture and the human health benefits: A case study in London. Environ. Pollut. 2009, 157, 2645-2653.

58. Donovan, G.H.; Butry, D.T.; Michael, Y.L.; Prestemon, J.P.; Liebhold, A.M.; Gatziolis, D.; Mao, M.Y. The relationship between trees and human health: Evidence from the spread of the emerald ash borer. Am. J. Prev. Med. 2013, 44, 139-145.

59. Ulrich, R. View through a window may influence recovery from surgery. Science 1984, 224, 420-421.

60. Lee, A.C.K.; Maheswaran, R. The health benefits of urban green spaces: A review of the evidence. J. Public Health 2011, 33, 212-222.

61. Schroeder, H.W. Environmental perception rating scales: A case for simple methods of analysis. Environ. Behav. 1984, 16, 573-598.

62. Kuo, F.E.; Sullivan, W.C. Environment and crime in the inner city: Does vegetation reduce crime? Environ. Behav. 2001, 33, 343-367.

63. Donovan, G.H.; Butry, D.T. Trees in the city: Valuing street trees in Portland, Oregon. Landscape Urban. Plan. 2010, 94, 77-83.

64. Akbari, H.; Pomerantz, M.; Taha, H. Cool surfaces and shade trees to reduce energy use and improve air quality in urban areas. Solar Energy 2001, 70, 295-310.

65. Akbari, H.; Taha, H. The impact of trees and white surfaces on residential heating and cooling energy use in four Canadian cities. Energy 1992, 17, 141-149.

66. McPherson, E.G.; Muchnick, J. Effects of street tree shade on asphalt concrete pavement performance. J. Arboricult. 2005, 31, 303-310.

67. IPCC. Climate Change 2014: Synthesis Report; Cambridge University Press: Cambridge, UK; New York, NY, USA, 2014.

68. Hoornweg, D. Cities and climate change: An urgent agenda. In Sustainable Low-Carbon City Development in China; Baeumler, A., Ijjasz-Vasquez, E., Mehndiratta, S., Eds.; The World Bank: Washington, DC, USA, 2012; pp. 3-32.

69. Nowak, D.J.; Crane, D.E. Carbon storage and sequestration by urban trees in the USA. Environ. Pollut. 2002, 116, 381-389.

70. Xiao, Q.; McPherson, E.G.; Ustin, S.L.; Grismer, M.E.; Simpson, J.R. Winter rainfall interception by two mature open-grown trees in Davis, California. Hydrol. Process. 2000, 14, 763-784.

71. City of Oakville. Urban Forest Strategic Management Plan, Town of Oakville: 2008-2027; Kenney, A., Ed.; Urban Forest Innovations Inc. (UFII), City of Oakville: Oakville, ON, Canada, 2008. Available online: http://www.oakville.ca/forestry.htm (accessed on 1 March 2015).

72. Wolf, K.L. Trees and business district preferences: A case study of Athens, Georgia, US. J. Arboricult. 2004, 30, 336-346.

73. Wolf, K.L. Business district streetscapes, trees, and consumer response. J. For. 2005, 103, 396-400. 
74. Giles-Corti, B.; Donovan, R.J. The relative influence of individual, social and physical environment determinants of physical activity. Soc. Sci. Med. 2002, 54, 1793-1812.

75. Gobster, P.H.; Westphal, L.M. The human dimensions of urban greenways: Planning for recreation and related experiences. Landsc. Urban. Plan. 2004, 68, 147-165.

76. Nowak, D.J.; Noble, M.H.; Sisinni, S.M.; Dwyer, J.F. People and Trees: Assessing the US Urban Forest Resource. J. Forest 2001, 99, 37-42.

77. Majumdar, S.; Deng, J.; Zhang, Y.; Pierskalla, C. Using contingent valuation to estimate the willingness of tourists to pay for urban forests: A study in Savannah, Georgia. Urban. For. Urban. Green. 2011, 10, 275-280.

78. Clark, K.H.; Nicholas, K.A. Introducing urban food forestry: A multifunctional approach to increase food security and provide ecosystem services. Landsc. Ecol. 2013, 28, 1649-1669.

79. Adams, L.W. In our own backyard: Conserving urban wildlife. J. For. 1994, 92, 24-25.

80. Alvey, A.A. Promoting and preserving biodiversity in the urban forest. Urban. For. Urban. Green. 2006, 5, 195-201.

81. Louv, R. The Nature Principle: Human Restoration and the End of Nature-Deficit Disorder; Algonquin Books: Chapel Hill, NC, USA, 2011.

82. Taylor, A.F.; Kuo, F.E.; Sullivan, W.C. Coping with ADD: The surprising connection to green play settings. Environ. Behav. 2001, 33, 54-77.

83. Hull, R.B.; Lamb, M.; Vigob, G. Place identity: Symbols of self in the urban fabric. Landsc. Urban. Plan. 1994, 28, 109-120.

84. Elmendorf, W. The importance of trees and nature in community: A review of the relative literature. Arboricult. Urban. For. 2008, 34, 152-156.

85. Kuo, F.E.; Sullivan, W.C. Aggression and violence in the inner city: Effects of environment via mental fatigue. Environ. Behav. 2001, 33, 543-571.

86. Jay, M.; Schraml, U. Understanding the role of urban forests for migrants-uses, perception and integrative potential. Urban. For. Urban. Green. 2009, 8, 283-294.

87. Qin, J.; Zhou, X.; Sun, C.; Leng, H.; Lian, Z. Influence of green spaces on environmental satisfaction and physiological status of urban residents. Urban. For. Urban. Green. 2013, 12, 490-497.

88. Toni, S.; Duinker, P.N. A framework for urban-woodland naturalization in Canada. Environ. Rev. 2015, in press.

89. Lopes, A.; Oliveira, S.; Fragoso, M.; Andrade, J.A.; Pedro, P. Wind risk assessment in urban environments: The case of falling trees during windstorm events in Lisbon. In Bioclimatology and Natural Hazards; Střelcová, K., Mátyás, C., Kleidon, A., Lapin, M., Matejka, F., Blaženec, M., Škvarenina, J., Holécy, J., Eds.; Springer Netherlands: Berlin, Germany, 2009; pp. 55-74.

90. McPherson, E.G., Expenditures associated with conflicts between street tree root growth and hardscape in California, United States. J. Arboricult. 2000, 26, 289-297.

91. Fisher, D.R.; Svendsen, E.S.; Connolly, J. Urban. Environmental Stewardship and Civic Engagement: How Planting Trees Strengthens the Roots of Democracy; Routledge: Oxon, UK, 2015.

92. Powell, A.S.; Lindquist, E.S. Effects of power-line maintenance on forest structure in a fragmented urban forest, Raleigh, NC. Southeast. Nat. 2011, 10, 25-38. 
93. Kovacs, K.F.; Haight, R.G.; McCullough, D.G.; Mercader, R.J.; Siegert, N.W.; Liebhold, A.M. Cost of potential emerald ash borer damage in U.S. communities, 2009-2019. Ecol. Econ. 2010, 69, 569-578.

94. Cariñanos, P.; Casares-Porcel, M. Urban green zones and related pollen allergy: A review. Some guidelines for designing spaces for low allergy impact. Landsc. Urban. Plan. 2011, 101, 205-214.

95. D’Amato, G.; Cecchi, L.; Bonini, S.; Nunes, C.; Annesi-Maesano, I.; Behrendt, H.; Liccardi, G.; Popov, T.; van Cauwenberge, P. Allergic pollen and pollen allergy in Europe. Eur. J. Allergy Clin. Immunol. 2007, 62, 976-990.

96. Talbot, J.F.; Kaplan, R. Needs and fears: The response to trees and nature in the inner city. J. Arboricult. 1984, 10, 222-228.

97. Koskela, H.; Pain, R. Revisiting fear and place: Women's fear of attack and the built environment. Geoforum 2000, 31, 269-280.

98. Jorgensen, A.; Anthopoulou, A. Enjoyment and fear in urban woodlands-Does age make a difference? Urban. For. Urban. Green. 2007, 6, 267-278.

99. Clucas, B.; Marzluff, J.M. Coupled relationships between humans and other organisms in urban areas. In Urban Ecology: Patterns, Processes, and Applications; Niemelä, J., Ed.; Oxford University Press: New York, NY, USA, 2011; pp. 135-147.

100. Lyytimaki, J.; Petersen, L.K.; Normander, B.; Bezak, P. Nature as a nuisance? Ecosystem services and disservices to urban lifestyle. J. Integr. Environ. Sci. 2008, 5, 161-172.

101. Fraser, E.D.G.; Kenney, W.A. Cultural background and landscape history as factors affecting perceptions of the urban forest. J. Arboricult. 2000, 26, 106-113.

102. Nowak, D.J.; Dwyer, J.F. Understanding the benefits and costs of urban forest ecosystems. In Urban and Community Forestry in the Northeast; Kuser, J.E., Ed.; Springer: New York, NY, USA, 2007; pp. 25-46.

103. Tyrväinen, L. Economic valuation of urban forest benefits in Finland. J. Environ. Manag. 2001, $62,75-92$.

104. Dwyer, J.F.; McPherson, E.G.; Schroeder, H.W.; Rowntree, R.A. Assessing the benefits and costs of the urban forest. J. Arboricult. 1992, 18, 227-234.

105. Pham, T.; Apparicio, P.; Séguin, A.; Landry, S.; Gagnon, M. Spatial distribution of vegetation in Montreal: An uneven distribution or environmental inequity? Landsc. Urban. Plan. 2012, 107, 214-224.

106. Landry, S.M.; Chakraborty, J. Street trees and equity: Evaluating the spatial distribution of an urban amenity. Environ. Plan. A 2009, 41, 2651-2670.

107. Wolch, J.R.; Byrne, J.; Newell, J.P. Urban green space, public health, and environmental justice: The challenge of making cities "just green enough". Landsc. Urban. Plan. 2014, 125, 234-244.

108. Nowak, D.J.; Stevens, J.C.; Sisinni, S.M.; Luley, C.J. Effects of urban tree management and species selection on atmospheric carbon dioxide. J. Arboricult. 2002, 28, 113-122.

109. Roloff, A.; Korn, S.; Gillner, S. The climate-species-matrix to select tree species for urban habitats considering climate change. Urban. For. Urban. Green. 2009, 8, 295-308.

110. Nowak, D.J.; Kuroda, M.; Crane, D.E. Tree mortality rates and tree population projections in Baltimore, Maryland, USA. Urban. For. Urban. Green. 2004, 2, 139-147. 
111. Miller, R.W. Urban Forestry: Planning and Managing Urban Greenspaces, 2nd ed.; Waveland Press Inc.: Long Grove, IL, USA, 1997.

112. Johnston, M. A brief history of urban forestry in the United States. Arboricult. J. 1996, 20, 257-278.

113. Lawrence, A.; de Vreese, R.; Johnston, M.; van den Bosch, C.K.; Sanesi, G. Urban forest governance: Towards a framework for comparing approaches. Urban. For. Urban. Green. 2013, $12,464-473$.

114. Steenberg, J.W.N.; Duinker, P.N.; Charles, J.D. The neighbourhood approach to urban forest management: The case of Halifax, Canada. Landsc. Urban. Plan. 2013, 117, 135-144.

115. Conway, T.M.; Urbani, L. Variations in municipal urban forestry policies: A case study of Toronto, Canada. Urban. For. Urban. Green. 2007, 6, 181-192.

116. Kenney, W.A.; Idziak, C. The state of Canada's municipal forests-1996 to 1998. For. Chron. 2000, 76, 231-234.

117. Jim, C.Y. Sustainable urban greening strategies for compact cities in developing and developed economies. Urban. Ecosyst. 2013, 16, 741-761.

118. Urban, J. Up by Roots: Healthy Soils and Trees in the Built Environment; International Society of Arboriculture (ISA): Champaign, IL, USA, 2008.

119. Bengston, D.N.; Fletcher, J.O.; Nelson, K.C. Public policies for managing urban growth and protecting open space: Policy instruments and lessons learned in the United States. Landsc. Urban. Plan. 2004, 69, 271-286.

120. Randrup, T.B.; McPherson, E.G.; Costello, L.R. Tree root intrusion in sewer systems: Review of extent and costs. J. Infrastruct. Syst. 2001, 7, 26-31.

121. Van Wassenaer, P.J.E.; Schaeffer, L.; Kenney, W.A. Strategic planning in urban forestry: A 21 st century paradigm shift for small town Canada. For. Chron. 2000, 76, 241-246.

122. Clark, J.R.; Matheny, N.P.; Cross, G.; Wake, V. A model of urban forest sustainability. J. Arboricult. 1997, 23, 17-30.

123. Konijnendijk, C.C. Enhancing the forest science-policy interface in Europe: Urban forestry showing the way. Scand. J. For. Res. 2004, 19, 123-128.

(C) 2015 by the authors; licensee MDPI, Basel, Switzerland. This article is an open access article distributed under the terms and conditions of the Creative Commons Attribution license (http://creativecommons.org/licenses/by/4.0/). 